\title{
There Was a Crooked Man(uscript): A Not-So-Serious Look at the Serious Subject of Plagiarism
}

Kevin T. McGuire, University of North Carolina at Chapel Hill

ABSTRACT The problem of plagiarism by political scientists has not received much attention. The incidence of plagiarism, however, may be greater than one would think. In this article, I offer a humorous look at what happened when a manuscript of mine was plagiarized. Based on my experience, I offer some suggestions on how scholars might detect and prevent plagiarism.

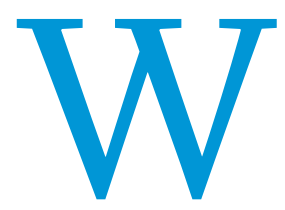

hat would you do if you found an article that you had written reprinted verbatim in another journal under someone else's name? Unlikely as it may seem, plagiarism is turning up in a good many scholarly publications. In fields as diverse as history and biomedicine, journals are awakening to the uncomfortable fact that many of the manuscripts that they receive-and often publish-have been previously printed elsewhere (Errami and Garner 2008; Lessoff 2007). The appropriate procedures for resolving such cases of intellectual theft are not at all clear (Glenn 2004), and thus scholars have had difficulty coming to terms with these lapses of academic integrity (Byrne 2008; Mallon 2001).

Political science seems to have been immune to the problem of plagiarism, but the absence of piracy among scholars in any field may be more apparent than real (Titus, Wells, and Rhoades 2008). Because their fraud would be too easily spotted if their handiwork were to appear in journals of wide circulation, "many apparent plagiarists [publish] in less-influential journals, perhaps to evade detection" (Guterman 2008, A9). Like any discipline, political science has its share of obscure outlets-tell the truth, when was the last time you read an article from the Review of Radical Political Economics or the Taiwan Journal of Democracy?-and by publishing in journals that appeal to a smaller subset of readers, a plagiarist can minimize the odds of exposure. Under such conditions, one is unlikely to know about plagiarism unless actively looking for it.

One widely reported illustration of the role of serendipity in detecting plagiarism in political science involves professor Steven Livingston of Middle Tennessee State University, whose article in International Studies Quarterly was plagiarized at length in a book entitled European Crisis Management in the 1980s, by Neil

Kevin T. McGuire is professor of political science at the University of North Carolina at Chapel Hill. His research on the U.S. Supreme Court has been published in a number of journals, including the American Political Science Review, the American Journal of Political Science, and The Journal of Politics. He is co-editor of Institutions of American Democracy: The Judiciary (Oxford University Press). He can be reached at mcguire@unc.edu.
Winn of the University of Leeds. For seven years, Professor Livingston was unaware that his words had been lifted until a Harvard University undergraduate discovered it while writing a senior honors thesis. The student's father, to whom he recounted the incident, just happened to be an academic and reported the plagiarism to Livingston. Were it not for this confluence of facts, the plagiarism might still be undetected (Bartlett and Smallwood 2004).

I know all too well the role of chance in uncovering plagiarism. It was only by happenstance that I learned that a one of my refereed articles was submitted by a plagiarist to another journal, where it was reviewed, accepted, and (re) printed.

This article describes my firsthand experience with my own case of plagiarism. Here, I detail the circumstances under which it occurred, the course of action I pursued, and how the issue was resolved. It is a cautionary tale about how readily one's work can be stolen and how political scientists, both individually and collectively, might confront it and guard against it. (Since my goal is to offer useful advice to others-not to expose the plagiarist in the hope of exacting some measure of retribution-I purposefully leave vague many of the vital details. ${ }^{1}$ )

\section{THE BACKGROUND}

Early in 2008, I attended the annual meeting of the Southern Political Science Association in New Orleans, and at the meeting's opening reception, I bumped into a recent graduate of our Ph.D. program. "So," she asked with a hint of conspiracy in her voice, "did you know that you've been plagiarized?"

"What?..."

"You've been plagiarized-and in print!" she enthused. Before I could inquire further, though, she turned and began scanning the reception for someone whom she obviously wanted to join the discussion. She quickly located him-a former colleague of a friend of mine from graduate school whom I had met several times-and pulled him into our conversation. Scarcely able to contain her excitement, she said, "Tell Kevin about his article being plagiarized."

He explained that graduate students at his home institution were given an assignment to trace the citation patterns of a 
scholarly article. A student had selected one of my publications, and in the course of tracking its subsequent citations, he stumbled upon another article that seemed to cover much of the same ground as I had in my piece. On closer inspection, the student determined that this article bore an uncanny resemblance to mine.

My acquaintance was unclear on some of the particulars. He couldn't recall which of my articles was involved. He had only a vague recollection of the journal in which it had reappeared; it was unfamiliar to him, a specialized publication and not a mainstream journal of political science. He assured me, however, that it would be easily found in my library's electronic resources.

Returning home, I set about trying to locate the article. Without knowing quite what to look for, I searched through various online journals that, based on their titles, seemed like possible candidates. After these efforts proved unsuccessful, I contacted my acquaintance who had relayed the story to me. Could he, I asked, help me find this publication? Within minutes, he returned an e-mail to which was attached a copy of the article. His memory having been refreshed, he was able to locate it immediately. He expressed his regrets, noting that it "really is despicable that someone would do this." He was right; I opened the attached file, and its contents were pretty dreadful.

What splashed across the electronic page was the banner of an unfamiliar European journal and its publisher. Everything that appeared under that banner was completely bewildering. In large, bold letters was the article's title, quite similar to the title of an article that I had published only a few years earlier. As I scanned the opening paragraph, I instantly recognized it as one I had written. A few minor alterations of language-all of which, I judged, did damage to my carefully crafted prose-were littered throughout various sentences, but it was unquestionably my own.

As I turned the electronic page, what followed was a continuation of my manuscript, almost exactly as I had written it. It continued on the next page. And the next. Browsing quickly through the article, I kept waiting for the author's own original contribution to appear, to pick up where my work might have left off, but each subsequent page confirmed that the author had simply taken my article and, with only the slightest bit of editing, submitted it to another journal. I had been plagiarized.

I was dumbfounded. ${ }^{2}$ Plagiarism was an offense committed by misguided undergraduates, I thought, not by contributors to scholarly journals. Mark Twain knew that "a certain amount of pride always goes along with a teaspoonful of brains, and that this pride protects a man from deliberately stealing other people's ideas" (2006, 135). Self-respect always inhibits the would-be plagiarist, and I reckoned that this would hold with particular force within the academic community, where there is a premium on intellectual integrity.

To be sure, I had heard of a few celebrated foibles-the Sokal hoax, the academic misconduct of Ward Churchill, St. Martin's Press cancelling a book denying the Holocaust-but the probability was small (epsilonic, in fact) that someone like myself, whose work is non-controversial and written for a fairly specialized audience, would be the target of such blatant theft. I couldn't fathom why some rogue pseudo-scholar would make off with and claim credit for an article whose principal audience was, even by the most generous self-serving estimate, scarcely a dozen people. Just who was he going to impress?

\section{TO PURSUE THE CASE, OR NOT?}

Initially, I was uncertain as to what course of action, if any, I should follow. Unfamiliar with any similar cases within political science, I sought the counsel of scholars whose professional judgment I trusted. Their reaction was fairly uniform; almost all recommended the same course of action: do nothing. The basic rationale was quite sensible. It was unlikely that anyone in my immediate subfield of judicial politics would ever encounter the plagiarist's version of the article. So, one of the arguments for exposing plagiarism-that there needs to be proper attribution in order to avoid confusion over authorship-held little sway; no one about whom I cared, they argued, would ever even know that an alternate version existed. (Who were they kidding? It was not clear that many people knew about my original article; after all, "the modal number of citations to articles in political science is zero" [King 1995, 445, emphasis in original].)

Since whatever damage done to me was negligible, the only result from my pursuing the case would be the expense of time and energy that could be channeled in more productive directions. One senior colleague in my department reminded me that I had actually received a kind of backhanded compliment, citing the old saw that "imitation is the sincerest form of flattery."

Perhaps this was a wise strategy, I thought. I should actually be pleased that my work was plagiarized. It had been accepted not once, but twice, and by completely independent and peerreviewed journals. My name was not associated with the second submission, so any claims that its publication was partially attributable to, say, the quality of my university or whatever reputation I might have within my subfield had been neatly eliminated. A natural experiment had demonstrated that my scholarship was really that good. Not only that, I told myself, there are thousands of academic manuscripts that are readily available on the Internet, and out of all those countless pages, my own humble work had been carefully chosen for resubmission to a journal. My plagiarist could have stolen from anyone, and he had chosen to steal from me. I was beginning to feel like Suzanne Somers's lucky suitor during her early career appearance on The Dating Game.

Other friends took a decidedly less charitable view and advised against such complacency. A spirited call for action came from these colleagues. Their attitude reflected an indifference to any damage to my professional reputation, focusing instead on the need for retribution. In fits of pique and profanity, more than a few exhorted me to "bring him down"-and double-quick. Surprisingly, such bitter bile came from otherwise passionate civil libertarians-righteous indignation, it turns out, trumps abstract political principle-and they demanded swift reprisal against my plagiarist through various measures that lacked any semblance of due process.

Weighing these two competing courses of action, I began to investigate my plagiarist. I started first with his published version of my manuscript, where a couple of red flags were waving on the very first page. His given name was Anglo, which seemed at odds with his academic affiliation, an unfamiliar German university. Perhaps, I thought, my plagiarist was covering his tracks, hoping that someone like me might be stymied when trying to locate him at a distant German school. (I was aware of at least one precedent. ${ }^{3}$ ) Moreover, his contact information listed a commercial e-mail account, rather than one from an educational institution. As one might have expected, an extensive search of this university's Web site revealed not a trace of my plagiarist. 
A more expansive exploration of the Internet bore fruit. His name, which was fortuitously distinctive, appeared on a number of different Web sites, none of which (YouTube, for example ${ }^{4}$ ) were maintained by a college or university. Some information suggested that he was on the faculty of at least two well-known schools, but neither one listed him on its roster. My plagiarist, it seemed, did not have a regular institutional affiliation, academic or otherwise. He did, however, take pains to make some aspects of his background available for public scrutiny. On one Web site, he had submitted a good deal of information about himself, much of it frustratingly non-specific about what would otherwise have potential consequences, some of which could be quite serious. One possibility was that my accusation could result in a counterclaim of libel by my plagiarist. This seemed a remote prospect, given that I had a large store of substantiating evidence on my side. Still, such things do happen in some plagiarism cases (see Hoffer 2004; Monasterksy 2007). Another possibility was that, once proven, my claim could produce fairly dire consequences for my plagiarist, including the loss of whatever academic post he might hold. And of course merely bringing the accusation had the potential to create public embarrassment to the journal editors who had, innocently enough, republished my work. Thus, I had to weigh

In fits of pique and profanity, more than a few exhorted me to "bring him down"-and double-quick. Surprisingly, such bitter bile came from otherwise passionate civil libertarians-righteous indignation, it turns out, trumps abstract political principle-and they demanded swift reprisal against my plagiarist through various measures that lacked any semblance of due process.

been crucial details in locating him. Academics tend to be sticklers about listing their degrees, carefully detailing where they were received and when. My plagiarist, by contrast, claimed that he had "attended" Harvard University and "went to" Columbia University. The obvious inference one was to draw was that he was both intellectually gifted and well educated, but his claims left enough room to be technically true yet wholly inaccurate. Going to a particular school is not the same as having a degree from that school..$^{5}$ If such leading institutions had conferred degrees upon him, he might well have noted that. My evidence to this point suggested that my plagiarist was not a fully fledged academic.

On this same site, he even placed a handsome, smiling photo of himself, posed as though momentarily indulging his photographer while diligently engaged in research, with pen in hand, legal pad and an open book across his desk. One observant colleague allowed that it looked as though he was busily copying another article.

What cinched my decision to make a formal accusation was not so much the piracy of my article as it was my plagiarist's decision to brag about "his" accomplishments after the fact. Academic associations routinely make space within their publications to list various accomplishments of note, such as their members' promotions or elections to various societies or positions of leadership. On one such Web site to which he had submitted a blurb, he noted that his work (read: my work) had recently appeared in a journal of distinction. To this point, I had done my best to reserve judgment. Maybe, just maybe, he took my manuscript in a moment of weakness because he desperately needed to get something into print in order to keep his job; that I could understand. But preening about it to a professional association afterwards was, well, a bit much.

Having made the decision to move forward, I resolved to do so with particular care. One political scientist in whose opinion I placed particular stock suggested that I should "proceed with caution, since making an accusation is a serious business." Even though I had treated the matter somewhat lightly to this point, I now began to realize that bringing my claim would have several the potential costs and decide what I would regard as a favorable outcome.

After some reflection, I decided that what I would seek would be a public acknowledgment by the journal that they had published a plagiarized article and that I, in fact, was the author. To the extent that I had been harmed, this would, I estimated, put things aright. As for seeking to punish my plagiarist, I decided against such a course of action. The lifelong professional damage it would exact on my plagiarist seemed highly disproportionate, and my perhaps overly developed Roman Catholic sensibilities suggested that he might actually seek redemption by one day accepting responsibility for his transgression. After all, the costs of living a lie may be exorbitant. Seeing one's name in print is surely gratifying, but even the fairly laidback New Testament does not paint a rosy picture of what awaits the unrepentant. There are more than a few references to fiery furnaces, wailing and gnashing of teeth, etc.

\section{MAKING AN ACCUSATION}

My first step was to contact the editors of the European journal. In retrospect, I acted fairly blindly. I didn't take the trouble to investigate whether this journal had specific procedures for making an allegation of plagiarism. Instead, I assembled the materials that I believed would be necessary to make a credible claim. This included an early draft of my manuscript, a copy of my published article, and a copy of my plagiarist's article that had appeared in their journal.

I included the draft version because, as I explained to the editors, the plagiarist had not submitted my published article but rather an earlier version that I had placed on my Web site. Prior to publication, my article had undergone extensive revision. As I compared the two publications, it became apparent that my plagiarist had not submitted my actual article but the earlier draft version. Trolling for a possible submission, he had evidently hit upon my Web site and decided that my manuscript was a strong candidate for submission to a journal. It was this draft that was subsequently published. I indicated that my only desire was for the journal to acknowledge its error and to recognize me as the genuine author. 
The same day that I conveyed this information to the editors, I received a response from one of them, thanking me for "bringing this matter to [their] attention." As he explained, "We shall take the contents of your e-mail very seriously, and I can assure you that we shall be investigating the issue you raise as a matter of urgency." Short of accepting my claim at face value, the editor had tendered what I regarded as a very promising response.

Three days later, I heard directly from the journal's publisher. In a very courteous and supportive message, a representative of the press indicated what steps would be followed, the first of which was contacting the author and giving him the opportunity to respond. She also referred me to the publisher's Web site, which contained extensive discussion of their standards and practices for claims of ethical misconduct. Many journals have no such formal policy (Lessoff 2007), but this press had comprehensively itemized how it dealt with such cases, and the procedures seemed to balance the need to take allegations of plagiarism seriously against the rights of the alleged offender to answer such charges. All that was left for me to do, it seemed, was await my vindication.

\section{WAITING (AND WAITING) FOR RESOLUTION}

Weeks passed, and no word arrived from the publisher. After two months-a reasonable amount of time, I judged-I contacted the publisher's representative, asking if there was any new information. A response followed the same day, advising me that the matter was still under review and that I would receive word as soon as there was something new to report.

Another month went by before I heard again from the publisher. The news was not encouraging. The pseudo-author had at long last responded to their inquiry, but, as the press's representative explained, "He did not comment on the issue that his article is almost exactly the same as the document you sent us." She promised to contact him again and to press him for an explanation.

This was baffling. How could this academic bandit answer a charge of plagiarism without "commenting on the issue"? Tempted though I was to ask to see his undoubtedly equivocal message, I responded with what I thought was a fairly strong argument. My manuscript was replete with tables containing the results of extensive data analysis. His published version, amazingly enough, had not a shred of statistical documentation. For whatever reason, the various tables included in my manuscript appeared nowhere in his paper. Although my results had been excised from his version, he nonetheless carefully edited and kept my language interpreting those results. ${ }^{6}$ Given that the two papers were virtually identical, I argued, there were two possibilities; either he had plagiarized me or I had plagiarized him. If it were the latter, I reasoned, why would I go to the trouble of fabricating the data analysis? Was it not singularly peculiar that I had a battery of empirics while his paper had none?

Another month came and went with no new word from the publisher, during which time I began to grow increasingly uneasy. What exactly was there to consider at such length? The publisher had my draft manuscript and my published article. What they published contained absolutely no original work from the plagiarist, and there could be no question that what they published was my own research. I had earlier expressed my willingness to share all manner of corroborating evidence. My intermittent work on the project dated back at least as far as five years prior to my article's publication. I had a number of electronic drafts of my paper, all neatly date stamped by word-processing software. I had countless e-mails that I had exchanged with various colleagues on issues relating to theory, literature, and quantitative method. I had a dog-eared folder fairly bursting with articles, data, and statistical results, as well as letters and reviews from at least two journals that had (unwisely, in my view) declined the opportunity to publish the paper. I was prepared, indeed eager to share all of this evidence with the journal's editors and the publisher. My case was so clear-cut that further investigation of my claim scarcely seemed warranted. The most likely explanation lay with my plagiarist, who I surmised was delaying any response in the hope that either I or the publisher would simply go away.

By this time, I had managed to locate the scoundrel on my own. This was no mean feat, since the information I had found placed him, truthfully or not, at several different academic institutions. It turned out that he held a position as an assistant professor at a community college in the Northeast, with a student population of around 7,00o. A great many cases of plagiarism are perpetrated by scholars who operate at the fringes of their disciplines (Byrne 2008), and in this sense my case turned out to be typical.

It was typical in another respect, as well; further digging revealed that this was not a first-time offense. The Internet, not surprisingly, is as much an asset to the victim of plagiarism as it is to the plagiarist himself, and armed with nothing more than a few choice phrases from four other pieces in which he credited himself as the author, I was quickly able to locate the previously published sources from which he stole two of them. Although I had chosen to take no action against my plagiarist, I obviously could not make that decision for these other authors and their journals. So, I informed the authors and journal editors that their articles had been plagiarized. (I received a note of encouragement from the editor of one of the journals, who charmingly referred to my plagiarist as a "dirtbag.")

Characteristically committing multiple transgressions, plagiarists often exhibit pathological behavior (Mallon 2001; Shaw 1982). ${ }^{7}$ Like other intellectual thieves, Professor X had not taken my work in a moment of weakness. Indeed, his modus operandi was to identify something for which he would like to have credit, repackage it listing himself as the author, and then ship it out to a journal for consideration.

This new information began to wear thin my patience, and while the editors and publisher had treated me with great decency, I began to wonder if they would be able to offer me a favorable resolution while they were waiting for an answer from someone whom I now had every reason to believe was busily hunched over a photocopier, turning out his latest scholarship. I decided to try a different approach to my problem.

\section{AN ALTERNATIVE STRATEGY}

To this point, I had been loath to invoke the legal process. Contrary to the popular conception of America's adversary culture, scholars in my field of judicial politics have long known that the vast majority of people who have legitimate civil claims are reluctant to pursue them (Miller and Sarat 1980-81; see also Haltom and McCann 2004). Still, in light of the lack of headway made by my efforts to get relief, I decided to explore possible legal remedies.

Being on good terms with an intellectual-property lawyer on the law faculty at the University of North Carolina, I sought her advice on what other tactics I might employ to thaw the process that, by now, had been frozen for 10 months. Her preliminary 
questions had more to do with the publisher of my own article, rather than the plagiarist's imprint-had I, for example, transferred the copyright to the publisher or merely given them license to publish my work?--and after some discussion, she allowed that, in her judgment, I had been following the wrong course of action.

Why not, she suggested, bring the matter to the attention of my publisher? After all, since an article that they had published had been plagiarized, they had a dog in the hunt, as well. More importantly, they no doubt had in-house legal counsel whose job it was to defend their press in precisely these situations. Something as simple as a letter from their lawyers addressed to their counterparts at the plagiarist's press might be all that was required to produce a speedy and sensible resolution. This would prove to be sage advice.

Acting on her suggestion, I wrote to both the present editor of my journal as well as the previous editor who had published my article. To my delight, the previous editor expressed not the slightest doubt that I had written the article. (We had exchanged a number of e-mails while my paper was under consideration, and he had requested that I make various statistical refinements to my original analysis.) I also had the good fortune of having a personal friendship with the current editor, and he wasted no time in passing along to the publisher all of the relevant details and documentary evidence as well as his support for my claim.

This did the trick. Within the month, my publisher's legal counsel contacted the plagiarist's press by phone and was able to secure what I had long awaited. When my press's representative contacted me, she told me to try to access the plagiarist's article online. When I did, she informed me, I would see that the article had been withdrawn from the journal.

It was true. Following the Internet link that she provided, I found that, although the article could still be accessed electronically, the text was now obscured by the appearance of "RETRACTED," printed diagonally in large red letters across every page. Anyone who sought to download the article would first be met with a notice to the effect that what they printed was, in fact, previously written by me. It also carried the citation to my own article. This, it seems, is a common method of putting plagiarism cases to rest (Glenn 2004).

Over the months while I was awaiting resolution of my claim, I had indulged my vanity and engineered all manner of flowery kowtowing that I imagined the publisher might employ in announcing my vindication to the world. Perhaps they might begin with: "It is with the deepest regret," or better still: "We cannot adequately convey our most sincere apology." A nice ending might say something like: "Professor McGuire deserves not only the credit for his scholarship but the utmost respect for the moral rectitude displayed during what has undoubtedly been a most painful episode." Phrases like these had swirled deliciously through my brain.

The actual text was considerably more antiseptic. It merely stated that the editors had learned that their article corresponded to my own written research, work that had appeared first in draft form on the Internet and later as a published article. Not quite the touching note of contrition that I had expected. Notable by its absence was the word plagiarism; the language was doubtless written by lawyers to safeguard the press's interests, and I could scarcely begrudge them for effectively representing their clients. The only minor irritation was the apology, which was not directed to me as one might have expected but rather to the hapless reader who, the publisher must have presumed, would be distraught to learn that the article had been subject to a manufacturer's recall. Little it mattered, though. It had taken a year, but in the end I received precisely what I wanted: an admission that what they had published was actually my work, not the work of my plagiarist.

\section{SOME RECOMMENDATIONS}

Plagiarism in political science probably exists to a greater degree than we realize. It would be easy to dismiss my experience as an isolated case, had I not learned of it through such an odd stroke of luck; a graduate student stumbled across it and mentioned it to a faculty member whom I, in turn, happened to encounter at a professional meeting. If one extrapolates from my case, it is plausible to assume that there is a non-trivial amount of plagiarism, sitting undetected in various academic journals and books. What might political scientists do to uncover those cases and to deter future ones before they arise?

My experience suggests some possible solutions, but one should be cautious in using my circumstances as a model upon which to base plagiarism policies. To be sure, in some respects, what transpired in my case was characteristic of what often occurs: only by chance did I discover that I had been victimized by a serial plagiarist. When I learned of the plagiarism, I did not know whom to contact, what procedures to follow, or how to best protect my interests. I encountered sympathy and support from the journals, but the process (at least from my perspective) dragged on far too long.

Yet my case was, in other ways, highly atypical. First and foremost, mine was an exceptionally flagrant case involving wholesale theft of my work. More often than not, such disputes center on little more than the alleged theft of a few passing phrases or a paragraph or two. Second, although I was ignorant as to the proper procedures, I had the advantage of knowing personally the editor of the journal that published my original article as well as an intellectual-property lawyer who was willing to share her expertise. Because of their assistance, my ordeal was resolved quite quickly. Many cases of plagiarism can drag on endlessly (Bartlett and Smallwood 2005; Mallon 2001). Finally, my experience, though occasionally exasperating, ended agreeably. Not everyone who has suffered plagiarism can enjoy that same satisfaction.

With these caveats in mind, I offer here a list of possible safeguards against plagiarism. Most of my suggestions are by no means unique-historians have been especially thorough in considering this issue (see, e.g., Hoffer 2004)-and some of these strategies have been deployed in other fields with varying degrees of success. No one recommendation is likely to serve as a universal remedy, and not all of these policies will have equal bearing across scholars, journals, or fields of research. Moreover, each involves certain burdens that would have to be assumed by various players, and those burdens should necessarily be weighed against the benefits they might provide.

\section{Institutionalized processes and sanctions}

There is no consensus across disciplines on what mechanisms are best for handling accusations of academic misconduct. Consequently, those who suspect that their work has been plagiarized may not know what course of action to pursue (Glenn 2004; Marris 2006). Those who believe that they have been victims of plagiarism are less likely to complain if there are no formal channels for considering their claims. Our associations, therefore, can 
promulgate procedures for handling accusations of intellectual dishonesty. The American Political Science Association has one such mechanism, a standing committee on Professional Ethics, Rights, and Freedoms that exists to ensure compliance with its standards of academic integrity. Aside from committees to investigate plagiarism, associations might cede that responsibility to the journal editor, with formal guidance on how to handle such cases. (Of course, some journals are freestanding; that is, they are not publications of a professional association, in which case the editor and the publisher would likely share that burden. More on that below.)

When plagiarism is proven, there are a number of sanctions available to an association. These include expulsion of the plagiarist from its membership, denying the right to participate in organized meetings of the association, and the refusal to consider manuscripts submitted to its journal.

\section{Publisher-based Investigations}

Journals that are not attached to a particular association do not have the benefit of an infrastructure of scholars that can institutionalize an investigatory arm. The onus thus falls on the publishers of such journals to ferret out and sanction plagiarists. Sage Publications, which brings a good many journals of political science to print, has established procedures for adjudicating cases of plagiarism, at least for some of its journals in history. When cases arise, a committee consisting of the editor, a lawyer, and a representative from Sage investigates the allegation (Byrne 2008).

\section{Computerized Text Searches}

As scholars in the harder sciences have learned, a good deal of plagiarism might never be detected were it not for the availability of software that can rapidly analyze thousands of texts and identify possible cases of theft (Errami and Garner 2008). Our professional associations could consider investing in such applications and undertaking similar text comparisons among digitally archived materials. Such analyses, which could be conducted at regular intervals (say, every five years), would serve to expose unknown cases and deter future ones.

\section{Conditions for Journal Submissions}

Preventing publication of a plagiarized manuscript is always preferable to confronting it after it is in print. One very simple mechanism for deterring plagiarists that is readily available to scholarly journals is the attachment of conditions to the submission of manuscripts. A journal might, for example, inform contributors of its readiness to investigate any suspected plagiarism at any point during the review process and to report its findings to the author's home institution. Similarly, an editor might reserve the right to ask for replication data to allow for independent confirmation of the reported results. Plagiarism is often not the dishonest academic's only transgression; many falsify data, too (Mallon 2001). Knowing that they can be held to close account if questions arise may be sufficient to discourage many would-be forgers from appropriating others' work. This recommendation is relatively easy to implement, and yet few scholarly journals appear to take advantage of it (Marris 2006).

The job of a journal editor is far more burdensome than most realize, and I do not mean to introduce an additional set of responsibilities to an already crowded plate. To the contrary, thwarting plagiarists before they submit to a journal obviates the need for editors to deal with such disputes after the damage is done. Putting plagiarists on notice that editors are prepared to act on their suspicions is one way of scaring off intellectual thievery.

\section{Expose Scholarship to a Broad Audience}

A basic condition for any claim of plagiarism is temporal sequencing; one must demonstrate that the plagiarized work appeared before the work in which it was plagiarized, not vice versa. Fortunately, the customary scholarly practices of presenting research at conferences, posting draft manuscripts to public Web space, and making replication data sets available upon publication solidify one's visibility within a particular field of research. The more one's work is known-and the earlier-the more difficult it is for plagiarists to pass it off as their own.

\section{Practice Self-policing}

Another simple way to detect plagiarism is for scholars to conduct their own forensic investigations. Online search engines, such as Google, are incredibly powerful and remarkably easy to employ. By searching for a handful of distinctive phrases from a manuscript, one can readily unearth possible cases of plagiarism. It was by this method that I was able to determine that my plagiarist was a serial offender; a little sleuthing on my part revealed the sources of two of his other publications. This option is already available to the paranoid, the self-important, or the merely curious.

\section{Secure Your Own Interests}

Victims of plagiarism may receive considerable encouragement from a number of different sources, but it bears emphasizing that there is no institutional voice designed to represent their interests formally. Moreover, what the victim regards as a desirable resolution to the case is not always the same as the preferred outcome of those who seemingly share the original author's interests. Deans or department chairs may fear unfavorable publicity and discourage those with legitimate claims of plagiarism from pressing them (Bartlett and Smallwood 2004; Wasley 2006). Likewise, journals may detect plagiarism during the review process; reviewers, for example, are often well positioned to bring such cases to the attention of the editor, and the editor may choose, quite reasonably, to reject the manuscript and admonish its author (Mallon 2001). In the absence of standard procedures, it is not clear that either the journal editor or the referee has an obligation to inform the victim. Consequently, the plagiarist remains free to start afresh at another journal, one whose editors and referees may be somewhat less vigilant.

Sadly, there is little professional reward for exposing one's plagiarist (LaFollette 1996). Perverse though it may be, plagiarists themselves are sometimes portrayed as the victims of an overly anal phalanx of the professoriate, armed with protractors to measure plagiarism by degrees and bent on destroying a productive scholar's career (Mallon 2001).

Scholars whose works have been plagiarized, therefore, need to proceed with the awareness that they are best situated to protect their own interests. A victim of plagiarism is uniquely positioned to appreciate the otherwise villainous Iago's advice to Othello on the importance of one's reputation: "he that filches from me my good name, robs me of that which not enriches him, and makes me poor indeed" (act III, scene iii). Plagiarism is theft, 
and the plagiarist steals not only an author's words but a part of the author's reputation by siphoning away the credit for that scholarly work.

\section{CONCLUSION}

Today, I am able to look back at my case of plagiarism somewhat lightheartedly. An unknown scholar walked off with one of my manuscripts and claimed it as his own, but it did no real damage to "my good name," inasmuch as no one, save the plagiarist, was likely ever to know about it. My case ended relatively quickly and, from my perspective, quite happily. Of course, my satisfaction with the outcome was highly subjective; in similar circumstances, other victims might make different choices, ranging from taking the whole matter in stride to seeking the most stringent forms of retaliation against the plagiarist. The choices I made were right for me.

One should not misconstrue my account as a general indifference to the problem of plagiarism. It is a deadly serious form of academic misconduct and needs to be treated as such. As the various popular accounts of plagiarism make plain, it is often an agonizing ordeal for the victims than can stretch out for years while their plagiarists often blithely carry on unpunished (Glenn 2004; Mallon 2001). The story of my experience with plagiarism and the suggestions I offer are meant only to draw attention to a problem that is potentially bigger than most imagine.

\section{NOTES}

I am grateful for the information, comments, and advice of Lawrence Baum, James Garand, Robert Hauck, William G. Jacoby, Jan E. Leighley, Alan Lessoff, Catherine E. Rudder, Lee Sigelman, and Frank Sorauf.

1. I have no desire to embarrass the editors of the journal who mistakenly published my work, and since I sought no retribution against my plagiarist, I do not identify him by name. In my view, the reader will gain little by knowing the identity of the plagiarist or the journal to which he submitted my work.

2. The sensation is similar to what one experiences when a college sweetheart announces, completely out of the blue, that she has been secretly dating the place kicker on the football team and has decided to end her relationship with you. (This actually happened to me. On subsequent game days, I had to endure the thunderous roar of thousands who cheered his every success. The pain was exquisite.)

3. In an episode of the television series MASH, Hawkeye and Trapper concoct the credentials of a fictitious officer named Captain Tuttle. When filling out the details of the personnel form for Captain Tuttle, Trapper suggests that they should list Harvard as his medical school. Knowing that this will make their ruse too easy to expose, Hawkeye demurs, saying, "No, we can't make it any place that they'll check." Thinking for a moment, Trapper suggests an alternative university, "How about Berlin Polytechnic?"

4. No, really. He's on YouTube.

5. Employing such nebulous prose, I could readily claim that I, too, "went to Harvard." Marie Hojnacki, a good friend from graduate school, and I regularly enjoy running together at professional conferences. The last time the APSA met in Boston, for example, we were running north along the Charles River. I could with plausibility assert that, in running to and past the campus, we both "went to Harvard." Come to think of it, we crossed the river and "went to MIT," as well.
In a similar illustration, a co-author of mine who had aggravated an old injury to one of his fingers was referred to a "Harvard-trained" hand specialist who judged the most expeditious medical treatment to be amputation of the finger and replacement with a prosthetic. "Harvard-trained," my colleague surmised, could have constituted little more than attending a one-day seminar addressing (what else) digital amputation.

6. This was one of the more bizarre aspects of my case. No journal of which I was aware was willing to accept statistical analyses on faith. How could a publication proceed in the absence of reported results? Other articles in the same journal were published with tables and figures. So, why were they so conspicuously absent in his article? My strong hunch was that the plagiarist feared having to explain, to the editors or the reviewers, empirical results that he either did not understand or was unable to replicate. That my article was so well written that it was accepted and published without supporting evidence was, I must confess, a substantial boost to my ego.

7. Some students of plagiarism have observed that plagiarists often have a "death wish," that is, they actually want to be caught and exposed (Shaw 1982). One of the other two journals from which my plagiarist lifted an article is of such high visibility that he must surely have calculated, even if only subconsciously, that someone would spot his handiwork.

\section{REF E R E N C E S}

Bartlett, Thomas, and Scott Smallwood. 2004. "Four Academic Plagiarists You've Never Heard Of: How Many More Are Out There?" The Chronicle of Higher Education 51 (17): A8.

_. 2005. "Just Deserts? Plagiarizing Professor Face A Variety of Punishments." The Chronicle of Higher Education 51 (30): A26.

Byrne, Richard. 2008. "History-Journal Editors Grapple with the Perils of Plagiarism." The Chronicle of Higher Education 54 (19): A8.

Errami, Mounir, and Harold Garner. 2008. "A Tale of Two Citations." Nature 451 (January 21): 397-99.

Glenn, David. 2004. "Judge or Judge Not." The Chronicle of Higher Education 51 (17): A16.

Guterman, Lila. 2008. "Plagiarism and Other Sins Seem Rife in Science Journals, A Digital Sleuth Finds." The Chronicle of Higher Education 54 (21): A9.

Haltom, William, and Michael McCann. 2004. Distorting the Law: Politics, Media, and the Litigation Crisis. Chicago: University of Chicago Press.

Hoffer, Peter Charles. 2004. "Reflections on Plagiarism, Part 2: The Object of Trials." Perspectives 42 (3): 21-25.

King, Gary. 1995. “Replication, Replication.” PS: Political Science and Politics 28 (3): 443-99.

LaFollette, Marcel C. 1996. Stealing into Print: Fraud, Plagiarism, and Misconduct in Scientific Publishing. Berkeley: University of California Press.

Lessoff, Alan. 2007. "Plagiarism and Historical Journals." Perspectives on History 45 (8): $46-47$.

Mallon, Thomas. 2001. Stolen Words: The Classic Book on Plagiarism. New York: Harvest Books.

Marris, Emma. 2006. “Should Journals Police Scientific Fraud?” Nature 439 (February 2): 520-21.

Miller, Richard E., and Austin Sarat. 1980-81. "Grievances, Claims, and Disputes: Assessing the Adversary Culture." Law \& Society Review 15 (3-4): 525-66.

Monasterksy, Richard. 2007. "Plagiarism, Prayer, and Fraud Play Roles in Lawsuit against Professor.” The Chronicle of Higher Education 54 (10): A10.

Shaw, Peter. 1982. "Plagiary." American Scholar 51 (Summer): 325-27.

Titus, Sandra L., James A. Wells, and Lawrence J. Rhoades. 2008. "Repairing Research Integrity." Nature 453 (June 19): 980-82.

Twain, Mark. 2006. "Holmes Breakfast." In Mark Twain Speaking, ed. Paul Fatout. Iowa City: University of Iowa Press.

Wasley, Paula. 2006. “The Plagiarism Hunter.” The Chronicle of Higher Education 52 (49): A8 